\title{
Bad Love Poem Mark 2
}

You thought the last one was bad

This is worse

\section{Robert James Conlon}

I've been walking around

Wearing a T-shirt

Covered in spew

Because it makes me think of you

When our eyes first met

Across a carpet

Full of jumping fleas

Butts and piss

Alien abductions at quarter to three

Your eyes made me think of

The outfall sewer

Flowing to the sea

You are everything to me

Like a supermarket pizza

Melted in its wrappings

Plastic and burning

Tongue and lips

Numb with no feelings

You make my heart

Pitter patter

Alright I'm lying, its splutter

When we're together

We're two crushed cans

Under a truck tyre

In our love gutter

You are everything to me

Like rabies, no 
More like the Ebola virus

Your kisses make me bleed

My joints begin to scream

As my organs try to leave the scene

Yes, you are an infectious disease

You should be quarantined

Isolated

To protect the rest of humanity

I'll show you how much I care

I'll never change my T-shirt

Now that's a commitment

Not many could bare. 